\title{
Dancing in the Dark? The westernmost "Cypriot" knot-headed pin from Aïn Smene (Morocco)
}

\section{Dancing in the Dark? El alfiler "chipriota" con cabeza enrollada más occidental, procedente de Aïn Smene (Marruecos)}

\author{
Thomas X. Schuhmacher \\ Universidad Autónoma de Madrid \\ thomas.Schuhmacher@uam.es
}

Recibido 05/06/2014

Aceptado 11/07/2014

\begin{abstract}
The present article presents a review of a singular find of a copper pin together with Bell Beaker items in a cave in Morocco. Although in the first publication of this piece Georges Souville already established a connection of the pin to the so called "Cypriot" knot-headed pins of Central Europe and the Eastern Mediterranean, this piece never found the attention it deserved and never entered in the distribution maps of this type of pins. The recent publication of new metal analysis of the pin and the accompanying Palmela point even led to a rejection of this identification and its chalcolithic dating and the assumption of a Early Iron Age/Phoenician chronology. Here we review again the whole context and the findings and their potential analogies. Finally the identification as a "Cypriot" knot-headed pin will be affirmed and the finding is seen as part of the Late Chalcolithic exchange of ivory and other prestige-goods between the Near East, the Maghreb and the Iberian Peninsula.
\end{abstract}

Key-words: Knot-headed pin. Palmela point. Bell Beakers. Morocco. Iberian Peninsula. Exchange. Prestige-goods. Ivory. Resumen

Este artículo presenta una revisión de un alfiler de cobre singular, hallado en una cueva de Marruecos junto con cerámica campaniforme. Aunque Georges Souville ya en la primera publicación de esta pieza estableció una conexión con las llamadas alfileres "chipriotas" de Centroeuropa y del Mediterráneo Oriental, ésta nunca recibió la atención que merece ni entró en los mapas de distribución de este tipo. La reciente publicación de unos nuevos análisis del alfiler y de la punta de Palmela, que la acompaña, llevaron incluso a rechazar esta identificación y su cronología calcolítica para asumir una datación en la Primera Edad del Hierro y la Época Fenicia. Aquí revisamos otra vez todo el contexto y los hallazgos y sus posibles analogías. Finalmente confirmamos la identificación de la pieza como alfiler "chipriota" y lo interpretamos como parte del intercambio de marfil y otros objetos de prestigio entre el Próximo Oriente, el Magreb y la Península Ibérica.

Palabras clave: Alfiler chipriota. Punta Palmela. Campaniforme. Marruecos. Península Ibérica. Intercambio. Objetos de prestigio. Marfil.

\section{Zusammenfassung}

Der vorliegende Artikel liefert eine Revision des außergewöhnlichen Fundes einer Kupfernadel, die in einer Höhle in Marokko zusammen mit Glockenbecherscherben zutage kam. Obwohl Georges Souville bereits in der Erstpublikation dieses Fundes eine Verbindung dieser Nadel zu den sogenannten "zypriotischen" Schleifennadeln, die sich in Mitteleuropa und dem Östlichen Mittelmeerraum finden lassen, herstellte, fand dieses Objekt nie die Aufmerksamkeit die es verdient hätte und wurde auch nie in die Verbreitungskarten dieses Nadeltyps aufgenommen. Die jüngste Publikation von neuen Metallanalysen der Nadel und der sie begleitenden Palmela-Spitze führte sogar zu einer Ablehnung dieser Identifizierung und ihrer chalkolithischen Datierung. Stattdessen wurde sie nun in die frühe Eisenzeit/Phönizische Zeit eingeordnet. Hier werden nun der gesamte Kontext, sowie die Funde und ihre Parallelen erneut vorgestellt. Schließlich bestätigen wir die Identifikation als "zyprische" Schleifennadel und betrachten sie als Teil des im späten Chalkolithikum zwischen dem Nahen Osten, dem Maghreb und der Iberischen Halbinsel ablaufenden Austauschs von Elfenbein und anderen Prestigeobjekten.

Schlagworte: Schleifennadel. Palmela-Spitze. Glockenbecher. Marokko. IberischeHalbinsel. Austausch. Prestigeobjekte. Elfenbein. 


\section{INTRODUCTION}

In the year 1971 the teacher Charles Rivollier undertook an excavation in the cave of Aïn Smene near the little village of Sidi Allal, about $12 \mathrm{~km}$ South of Fez (Morocco). Before his death he handed his notes and documents of his work over to Georges Souville, who published the finds in an article in 1989 (Souville, 1989). Rivollier differentiated in the cave from top to bottom a superficial layer, a black one, a red one, a sterile stalagmitic deposit and at last, a rosé one. The black and ashy deposit, which had a thickness of $1 \mathrm{~m}$, produced a rich industry. This was mainly found at the base of this black layer, almost in contact with the red one. It contained a silex and polished stone industry, bone tools, ceramics and two metal objects. Among the lithic industry are one trapezoidal transverse arrowhead and another barbed and tanged one, a borer, a knife with backed edge, different blades and denticulated blades, flakes and cores. There were also two axes, two axe fragments, two stones with a small depression (pierre à cupules) millstones and a fluted club. Among the bone industry are punches and a smoothing tool. The ceramics consist mainly of 33 decorated Bell Beaker fragments. The two metal objects which accompanied these finds are a Palmela point and a possible knot-headed pin (Schleifennadel). Souville already related this pin with similar ones from the Eastern Mediterranean and interpreted the rest of the finds as another piece of evidence for the contacts between the Iberian Peninsula and the Maghreb in the Chalcolithic. But this find has never been taken in consideration in respect to the overall distribution of the knot-headed pins and lately this identification and chronology even have been put in doubt (Montero et al., 2012), which induced us to publish this review.

\section{THE KNOT-HEADED PIN}

\section{Description of the find}

The pin is complete with an overall length of 9,4 $\mathrm{cm}$ and a weight of 7,93 $\mathrm{g}$ (fig. 1). It shows four loops at the head and six loops around the stem. Following the analysis published by Souville the pin is made of almost pure copper ${ }^{1}$. Recently the pin was examined once again and analysed by Energy-Dispersive X-Ray Fluorescence analysis (ED-XRF) by I. Montero and his team at the National Archaeological Museum (MAN) in Madrid (Montero et al., 2012: table 1). The result was almost the same with $99,3 \%$ of copper.

\section{The pin from Loma de Boliche}

Montero et al. (2012) reject there the idea of the pin being a "cypriot" knot-headed pin (Schleifennadel) and prefer to compare it with a similar object from the

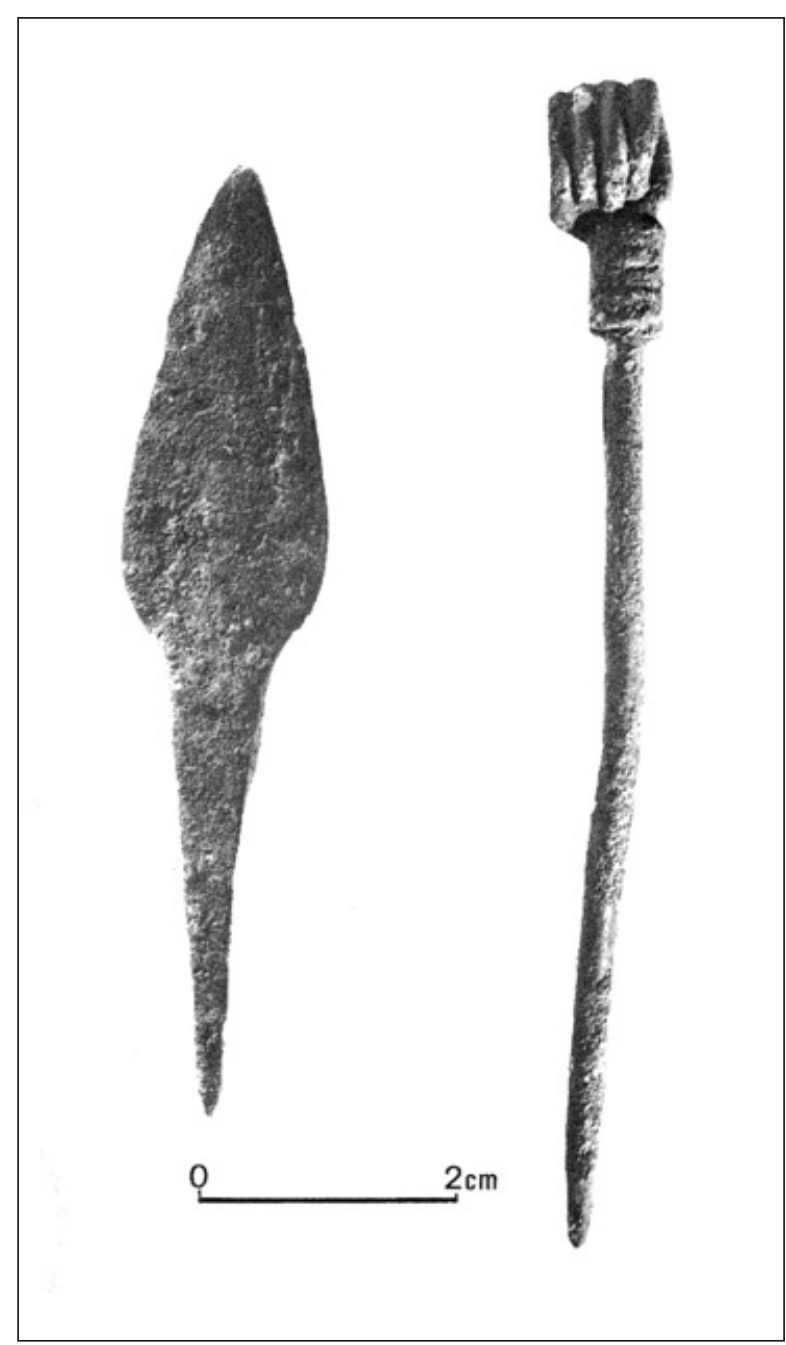

Figure 1. Aïn Smene (Morocco). Knot-headed pin and Palmela point. (after Souville, 1989: fig. 4)

necropolis of Loma de Boliche (Herrerías, Almería, Spain) (fig. 2,7). This object comes from the simple pit grave 40 of this necropolis (Siret, 1906: 433 fig. 34. 36,40; 37,1; Siret, 1913: 160f fig. 31,7; Osuna Remesal, 1981: 394 fig. 3,1.2.4; 13; Lorrio, 2008: $90 f$ fig. 36). The pit measured $1,2 \mathrm{~m}$ to $0,4 \mathrm{~m}$ with a depth of $0,85 \mathrm{~m}$. Stratigraphically it was situated below grave 41. It contained burned bones, a lamp and a plate made of ceramic, the bronze needle in question, two bracelets, fragments of a third one and two pendants made of silver. In the stores of the Archaeological National Museum (MAN) in Madrid, where this part of the collection of Luis Siret was stored, only the plate, two bracelets and fragments of a third one could be found, so that the needle is missing. Osuna and Remesal dated the finds of the necropolis of Loma de Boliche as a whole to the $7^{\text {th }}$ and $6^{\text {th }}$ century BC.

1 Sn 0,01\%; Pb 0,1\%; As 0,1\%; Ag 0,02\%; Fe 0,05\%. Souville, 1989: note 25. 28. 
Siret defines the object in question as a spatula (espátula de bronce) and not a pin, because one ending does not taper to a point, but is broadened. His foreman, P. Flores, who conducted the excavation and wrote the excavation report, does call it a pin (alfiler). The other end shows two loops on the head and four around the stem. Following the report by P. Flores and the stratigraphic section, published by Siret, it seems like we are talking about a closed find lying under tomb 41 (Osuna - Remesal, 1981: fig. 2). Therefore we will have to accept the dating for this object given by the grave goods in the tomb and the general dating for the necropolis, i.e. the $7^{\text {th }}$ and $6^{\text {th }}$ century BC.

Similar objects with one end terminating in a little spoon and probably used as toilet articles, but without the windings around the stem, are known from other sites on the Iberian Peninsula, like El Palomar (Oliva de Mérida, Badajoz) and Palhais (Beringel, Beja) (Rovira et al., 2005, 1235 fig. 2,19; Santos et al., 2010). For the piece of El Palomar, whose proximal ending is missing, we do have a metal analysis, indicating a bronze object.

The "pin" from Douïmès

Siret already related the pin from Loma de Boliche not only with the knot-headed pins (Schleifennadeln) found in the Eastern Mediterranean and Central Europe, but also with another object from the necropolis of Douïmès (Tunisia) (Siret, 1913: 160f fig. 31,6). The latter object is made of silver and shows one loop on the head and two on the stem (fig. 2,6). The other end is broadened and terminates in a sort of little spoon. Therefore clearly we have to differentiate it from the "Cypriot" knot-headed pins and have to define it, as the excavator Delattre (Delattre, 1897: 30-33 fig. 13) did, as a toilet article, assigned probably for the cleaning of the ears (cure-oreilles).

This object belongs to the necropolis excavated by A. L. Delattre from 1892 to 1896. The documentation of these excavations is quite sparse. Delattre only publishes a selection of the grave-goods and not all of them. In this case the object under question comes from a cist-grave made out of stone slabs. It contained a big quantity of objects, many of them ornaments of gold and silver. One of these objects, a golden disk-pendant, finds close parallels in form and decoration in several Phoenician and Early Iron Age necropolises of the Iberian Peninsula, like Trayamar (Málaga, Spain) and Medellín (Badajoz, Spain), and the Western and Central Mediterranean, like Ibiza, Motia, Sulcis and Malta (Almagro-Gorbea, 2008: 374376 figs. 482-483). These amulets all date to the second half of the $7^{\text {th }}$ and first half of the $6^{\text {th }}$ century BC. Although, because of the rudimentary methods of excavation and documentation, we have to admit the possibility that not all of the objects might share the same dating, we would not doubt to atribute the same dating also to the cure-oreilles from the tomb of Douïmès. This would also coincide with the date given to tomb 40 of the Loma de Boliche.

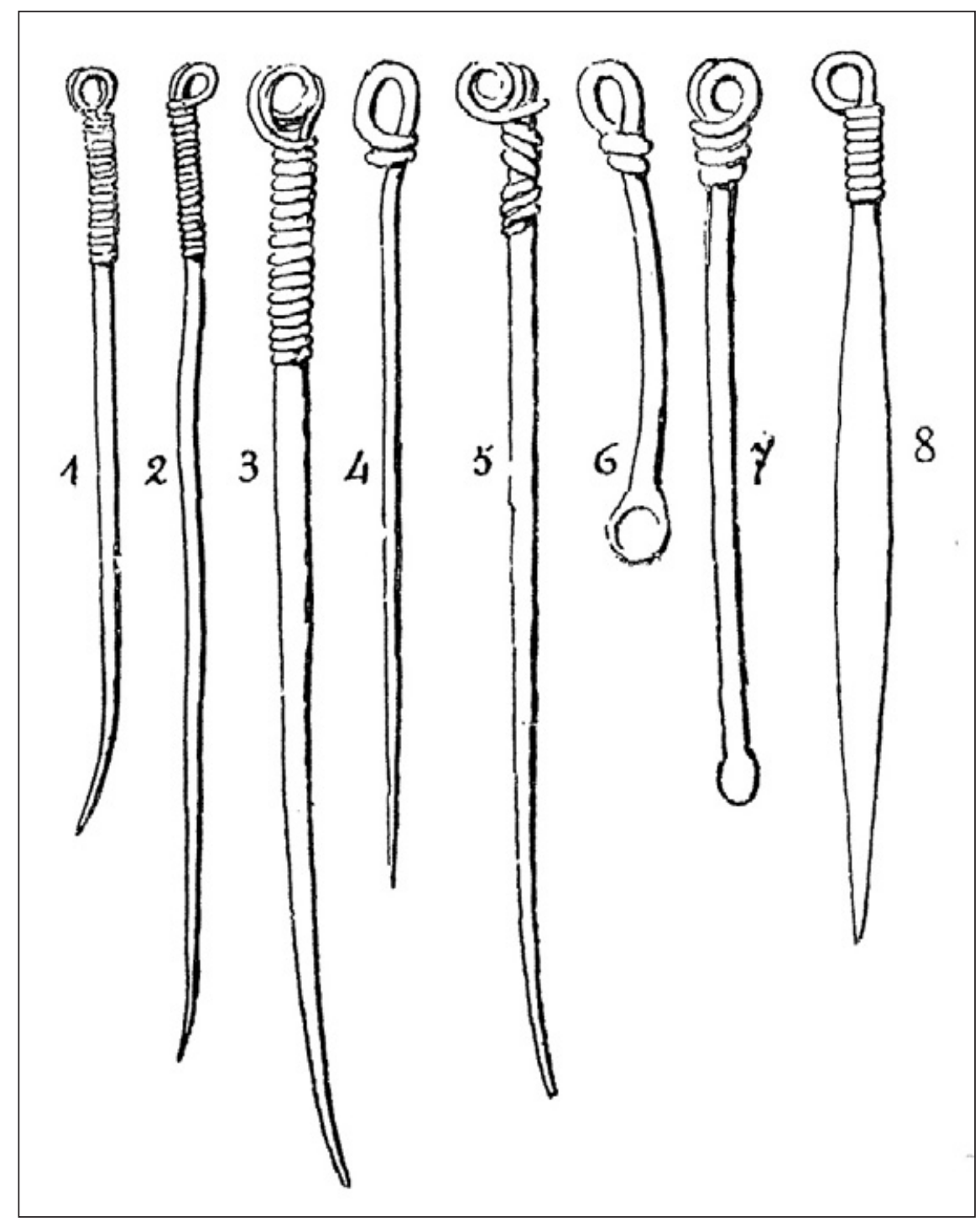

Figure 2. Knot-headed pins and similar pieces. 6 Douïmès (Tunisia); 7 Loma de Boliche (Herrerías). (after Siret, 1913: fig. 31) 


\section{The "CYPRIOT" KNOT-HEADED PINS}

Souville (1989) already compared the pin from Aïn Smene with the so called "Cypriot" knot-headed pins. This group of objects was last treated by Korfmann (1992: 24-27 fig. 21a), Gerloff (1993: 69-73 fig. 6 list 2) and Maran (1998: 448f pl. 78). These pins are first present in Egypt and the Near East since the end of the $4^{\text {th }}$ millenium BC (fig. 3). In the first half of the $3^{\text {rd }}$ millennium $\mathrm{BC}$ we also can find them in Mesopotamia and Asia Minor. It seems like these pieces or their design were transmitted at the end of the $3^{\text {rd }}$ millennium BC from Asia Minor to South-eastern and Central Europe. So a pin of this type forms part of the famous deposit of Kyhna (Saxony) (Miketta, 2011). The oldest Central European pieces belong to the phase Bronze A1 (Gerloff, 1993: 69-73 list 2). Until now, the examples from Switzerland and the Rhone valley were thought to be the most western ones. Bertram (2002), on the other hand, drew the attention to their presence in the Caucasus region in the second and third quarter of the $3^{\text {rd }}$ millennium and at the beginning of the Late Bronze Age.

It seems like the oldest forms are made of copper and show only one overhead loop, whereas the later ones, dating in Central Europe to Bronze A2 and in the Aegean and Cyprus to the first half of the $2^{\text {nd }}$ millennium BC, do have at least five, but normally seven or more overhead loops (Gerloff, 1993: 62f. 68-73). In Central Europe the older ones are mostly made of copper, the later ones of bronze. If we can apply these criteria, this could mean that we might be able to date the piece from Aïn Smene before Bronze A2.

\section{The aCCOMPanying Finds in Aïn SMene}

\section{The Palmela point}

The pin was found in the couche noire of the cave together with a Palmela point, polished stone and silex industry and Bell Beaker fragments (Souville, 1986) (fig. 1). Except for the Palmela point and the Bell Beakers, most of the finds are not diagnostic, only the two arrowheads might support a Neolithic date. The Palmela point shows a lanceolate blade and a shaft which narrows towards the end. It has an overall length of $7,15 \mathrm{~cm}$, a maximum width of $1,6 \mathrm{~cm}$ and weighs $7,16 \mathrm{~g}$. It belongs therefore to the smaller examples of Palmela points, which are the most numerous group (Gutiérrez Saéz et al., 2010: 406f). In contrast to the pin it is made out of copper with a percentage of $2 \%$

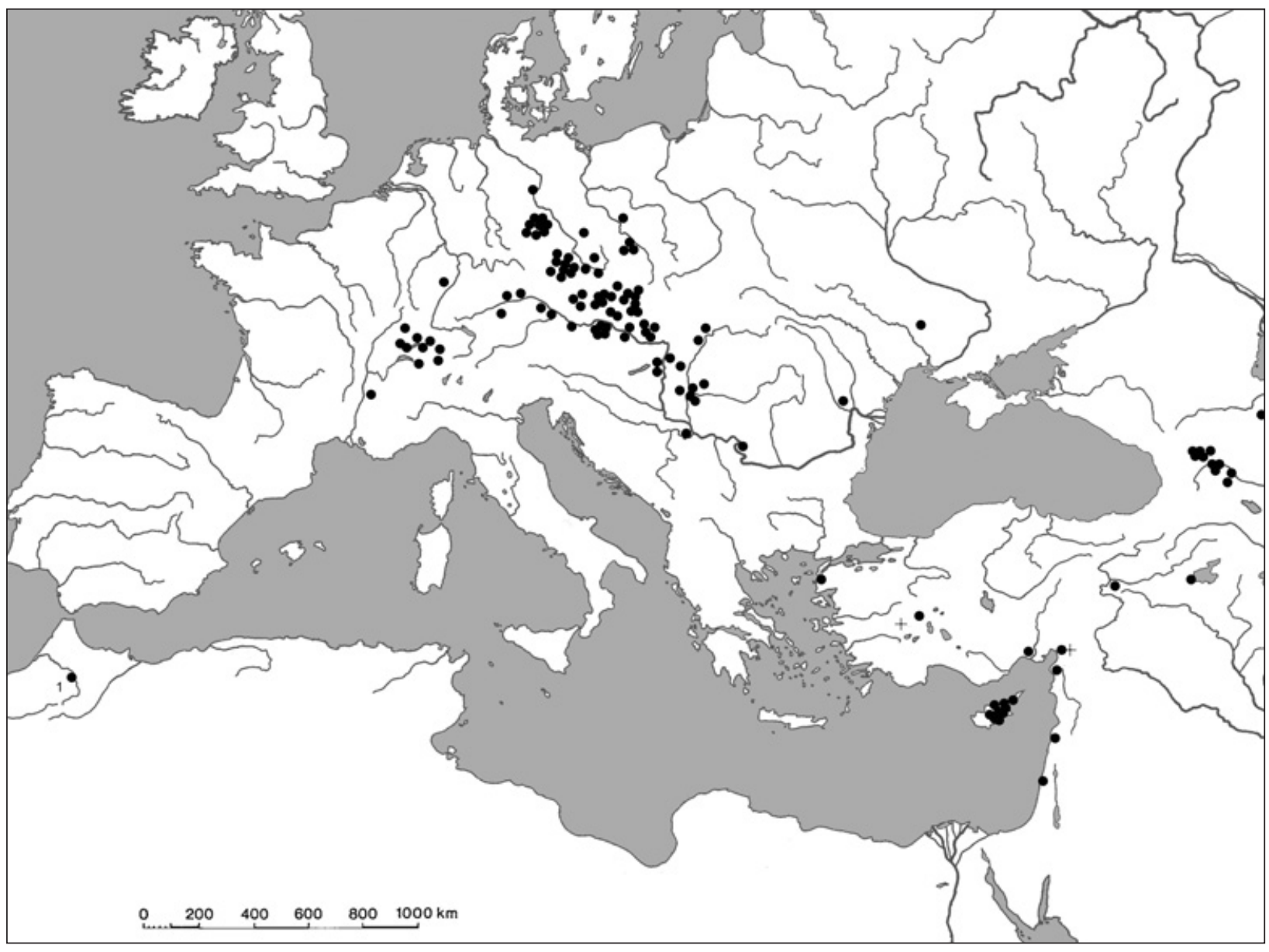

Figure 3. Geographical distribution of the knot-headed pins.

(Map modified by the author on the basis of Maran, 1998: pl. 78) 
of $\operatorname{arsenic}^{2}$. Although the new analysis undertaken by Montero et al. shows a slightly lower percentage of arsenic, we are still talking without any doubt about arsenical copper. Another Palmela point from Morocco, which came out of the cave of Ifri $n^{\prime}$ Amr or Moussa and was also analysed on that occasion, consists of almost pure copper (Bokbot - Ben-Nçer, 2008: fig. 3; Montero et al., 2012). This coincides with the situation on the Iberian Peninsula, where $77 \%$ of the Palmela points are made of almost pure copper and 22\% of arsenical copper (Delibes et al., 1999: $85 \mathrm{f}$ table 14; Hurtado - Hunt, 1999: 300).

Aprt from these two Palmela points, as already mentioned, some more were found in North-western Africa at several places, so in Sidi Messaoud (Casablanca), Aïn Dalia el Kebira (Tanger), El Heriga (Oujda, all Morocco), Karrouba and La Stidia (both Mostaganem, Oran, Argelia) (Souville, 1965: 417. 420 fig. 5 pl. 87,2; Ponsich, 1970: 50 pl. 9; Harrison Gilman, 1977: 95; Poyato - Hernando, 1988: 326 fig. 2,8; Wengler, 1983/84: fig. 1; Bokbot, 2005: 147 figs. 33. 40. 41; Grébénart, 1988: 54 fig. 9,1.3; Schuhmacher (in press)). Only the pieces of Aïn Dalia el Kebira and Ifri n'Amr have been found in clear grave contexts, the others came from caves or are isolated finds. For the two pieces named first, a Late Chalcolithic or Early Bronze Age date, not only because of the Palmela points themselves, but also the accompanying material, seems to be clear.

On the Iberian Peninsula we find Palmela points in grave and settlement contexts during Bell Beaker times and the early El Argar culture (Harrison - Gilman, 1977: fig. 10; Harrison, 1977: fig. 24; Garrido, 2000: 172-179; Briard - Roussot-Larroque, 2002: fig. 4; Gutiérrez et al., 2010). They do show concentrations on the Northern Meseta, in Valencia, the Southwest and especially the Tagus estuary. At the same time we can register several pieces in France. Regarding their chronology, the oldest example, found within a stratigraphic context and related with a radiocarbon date, still seems to be the one from level IIC of Cerro de la Virgen (Delibes - Fernández-Miranda, 1981: 157.180182). This level dates to 2344-2151 calBC $^{3}$. In Los Husos (Álava) a Palmela point comes from level IIB3. The underlying level IIC is dated to I-3985: $3920 \pm$ $100 \mathrm{BP}=2568-2215$ calBC (Apellániz, 1974: 231f). In the fortification of Zambujal (Portugal) a Palmela point is related to the latest phase 5 , which is dated by

2 As 2,0 \%; Sn 0,03\%; Pb 0,05\%; Sb 0,003\%; Ag 0,02\%, Ni $0,001 \%$; Bi $0,004 \%$; Fe 0,05\%; Mn 0,003\%. Souville 1989: $12 \mathrm{f}$ notes 25.28 .

3 GrN-5598: $3835 \pm 35$ BP = $2344-2206$ calBC; GrN-5764: $3800 \pm 35$ BP $=2290-2151$ calBC. Schuhmacher, 2012: two radiocarbon dates to 2431-1698 calBC. In any case Palmela points seem to be linked especially to later Bell Beaker contexts, like Ciempozuelos in Central Spain (Gutiérrez et al., 2010: 405f). Souville already concluded that all pieces from the Maghreb, with the exception of the one from Sidi Messaoud, represent Delibes' type $\mathrm{C}$, attributed by this author to the latest contexts with Palmela points (Delibes, 1977: 108-111 fig. 34; Souville, 1989: 12f). Rovira et al. basing themselves on technical arguments also considered type A to be the oldest and $\mathrm{C}$ the youngest (Rovira et al., 1992: 278).

\section{The Bell Beaker sherds}

Apart from five undecorated sherds, the "couche noire" also contained 33 Bell Beaker fragments (fig. 4). Most of them are comb decorated, some show a combination of comb and corded decoration. Among them are maritime Beaker decorations, zig-zags filled with oblique lines, chevrons, lozenge patterns and triangles. The fragments can be completed to bowls and shouldered bowls (cazuelas). We can find parallels for both, form and decoration, in the Tagus estuary, especially the Palmela complex (Souville, 1989: 10-12 fig. 3; Harrison, 1977: fig. 62,959; 64,1009; 65,1037; Soares - Tavares da Silva, 1984: fig. 5; Kunst, 1987: fig. 47, S1. S2. S6. S8. S13. S14. S16. S17. S18a. S19b. S25), and also in the Guadalquivir valley (Harrison, 1976: figs. 13,55.58.59; 16,64.65; 19,76, 21,84; 24,111; 33,193; Harrison, 1977: figs. 80,1505; $81,1627)$.

If we take in account that on the Iberian Peninsula Maritime Beakers disappear completely after 2000 calBC, this date could mark the lowest possible dating for the couche noire of Ain Smene (Castro et al., 1996: 107; Lazarich, 2005: 357 fig. 4). In other eleven Moroccan and two Algerian sites we do find Bell Beaker sherds (Bokbot, 2005; Schuhmacher (in press)). Most of them came from unclear contexts or sediments in caves and rock-shelters. Exceptions are the finds of Sidi Slimane and Ifri n'Amr or Moussa where we are talking about grave contexts. Among this ceramics are, as in Aïn Smene, Maritime Beakers and others which do find parallels in the Tagus estuary, especially the Palmela complex, and the Guadalquivir valley. Probably we are dealing with true imports from the Iberian Peninsula.

Catalogue 3. All radiocarbon dates in this text have been calibrated by $\mathrm{OxCal}$ v.4.2.3 at a range of 1 sigma (Bronk Ramsey, 2009). 


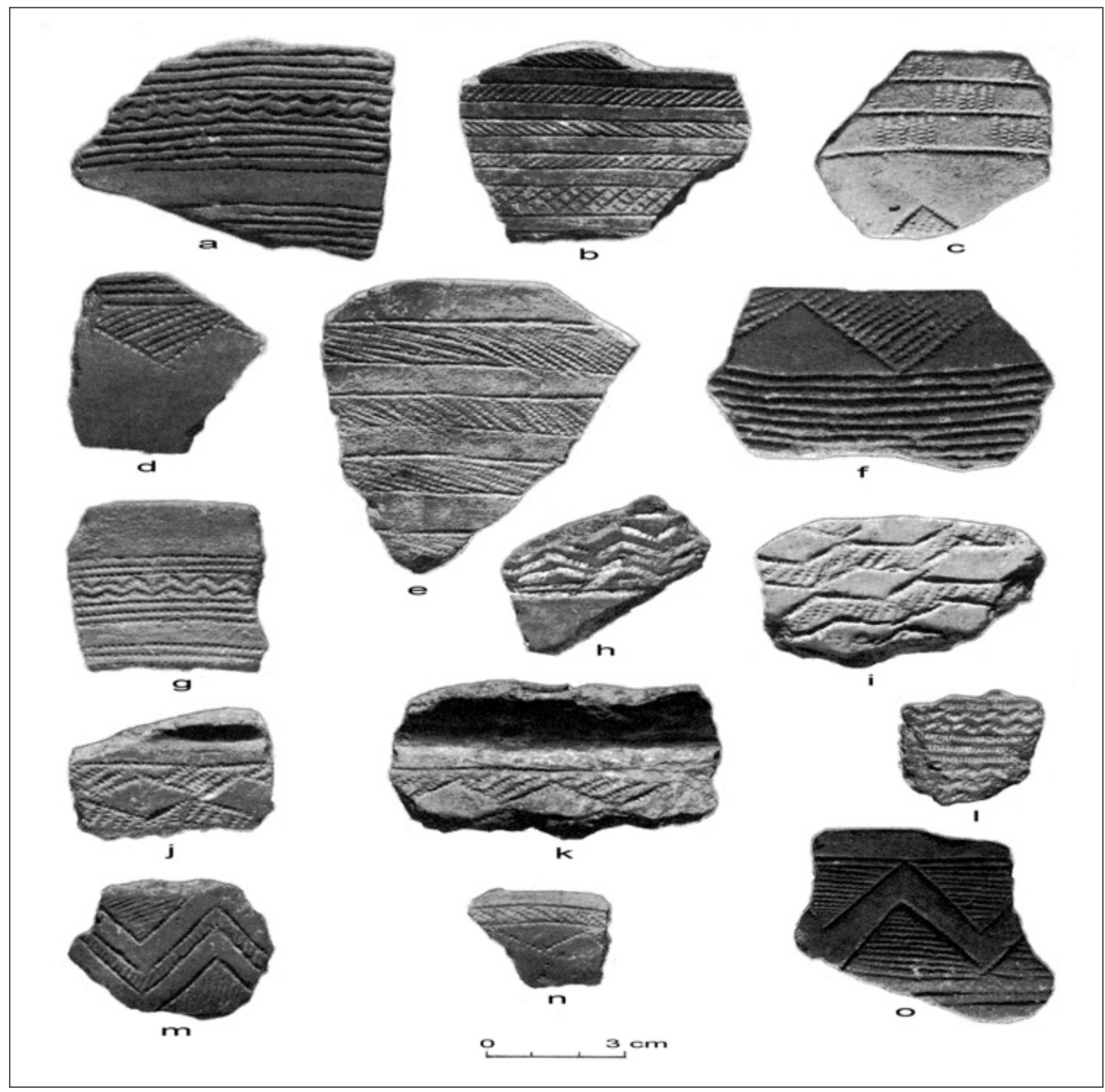

Figure 4. Aïn Smene (Morocco). Bell Beaker fragments. (Souville, 1989: fig. 3)

\section{Conclusion}

Of course, the information about the excavation in Aïn Smene and the techniques applied are quite sparse and we are talking about the work of a non-professional. In spite of this and the fact that we do not know how much time it took to accumulate the couche noire in Ain Smene, so we have to take into account that it has got a thickness of $1 \mathrm{~m}$, the material it contained seems quite homogenous (Souville, 1989). The parallels for the Bell Beaker vessels from Aïn Smene, which we can find among Maritime Beakers and such from the Tagus and Guadalquivir estuary, suggest a dating of the couche noire to the last third of the $3^{\text {rd }}$ millennium $\mathrm{BC}$. The same chronology is given by the accompanying Palmela Point. This dating would be fully compatible with the dating of the knot-headed pins in Central Europe and the Eastern Mediterranean, in the case that we accept this identification. The material, copper, and the type of the pin indicate that we are talking about an older variant of knot-headed pins, which date before the turn of the millennium. So from a chronological point of view there is no impediment for an identification of this piece from Aïn Smene as a "Cypriot" knotheaded pin. The supposed Phoenician and Early Iron Age parallels from Douïmès and Loma de Boliche on the contrary differ quite clearly from our piece. The only argument against this identification could be the fact that until now we do not know any knot-headed pins from the whole zone west of the Rhone valley. But this does not seem to be a solid argument against such an identification. Therefore we do not see any indication for a possible contamination of the sediment in Aïn Smene with later material, as the whole material seems to be homogenous and fully compatible with a 
dating in the last third of the $3^{\text {rd }}$ millennium $\mathrm{BC}$. We therefore confirm the original affirmation of Souville (1989), that in fact we do have a real knot-headed pin in Aïn Smene, found together with Bell Beaker and other "Neolithic" material, and reject the suggestion of Montero et al. (2012) of a later dating. This forms therefore the westernmost find-spot for such a pin.

Much more difficult it is to explain how this piece could have found its way to the West? At this moment in the whole Maghreb there are no other Central European or Eastern Mediterranean materials dating to the Chalcolithic. Nevertheless, we cannot exclude the possibility of direct contacts between the Maghreb and the Eastern Mediterranean. However, we have to enumerate different kinds of supposedly imported items, which confirm contact and exchange between the Iberian Peninsula and the Maghreb at that time (Harrison - Gilman, 1977; Bokbot, 2005; Schuhmacher et al., 2011; Schuhmacher (in press)). This refers to Bell Beaker vessels, Palmela points, a halberd, a tanged dagger, copper awls and a wristguard, all unearthed in the Maghreb, and the presence of African ivory in the Southwest, Southeast and Centre of the Iberian Peninsula. We therefore suggest an exchange of these prestige items for ivory between elites from the Iberian Peninsula and their emerging counterparts in the Maghreb, as Harrison and Gilman (1977) already did (fig. 5). In the Maghreb we can find this imported material especially in the North near Tangier, the Atlantic coast between Rabat and
Casablanca and the region of Oran. The parallels for these objects point especially towards the Guadalquivir and Tagus estuary, as do the above mentiond comparisons for the Bell Beakers from Aïn Smene.

Especially in the Guadalquivir estuary, and also the Southeast of the Iberian Peninsula, we could detect not only African but also Asian ivory at that time (Banerjee et al., 2011; Nocete et al., 2013; García Sanjuán et al., 2013). It therefore seems possible that in this framework of an import of Asian ivory from or via Syria also some eastern knot-headed pins could have reached the Iberian Southeast and Southwest, although we still have not found any piece. Here we have to recall other East Mediterranean metal elements dating to the end of the $3^{\text {rd }}$ millennium $\mathrm{BC}$ and found on the Iberian Peninsula, as the javelin heads from La Pastora (Valencina de la Concepción, Seville) and a possible slotted spearhead of Aegean/Anatolian type (Schlitzblattlanzenspitze) from Granada (Mederos, 2000; Schuhmacher, 2004; Brandherm, 1996). We have to remind, that a slotted spearhead and a knotheaded pin appear together in the deposit of Kyhna (Saxony) (Miketta, 2011). At least once, such a knotheaded pin could have been exchanged from the Guadalquivir area to the Atlantic coast of Morocco in exchange for African ivory and from there to the area of Fez (Aïn Smene). Because of the clear parallels between the Bell Beakers of Ain Smene and the Guadalquivir valley and the simultaneous appearance

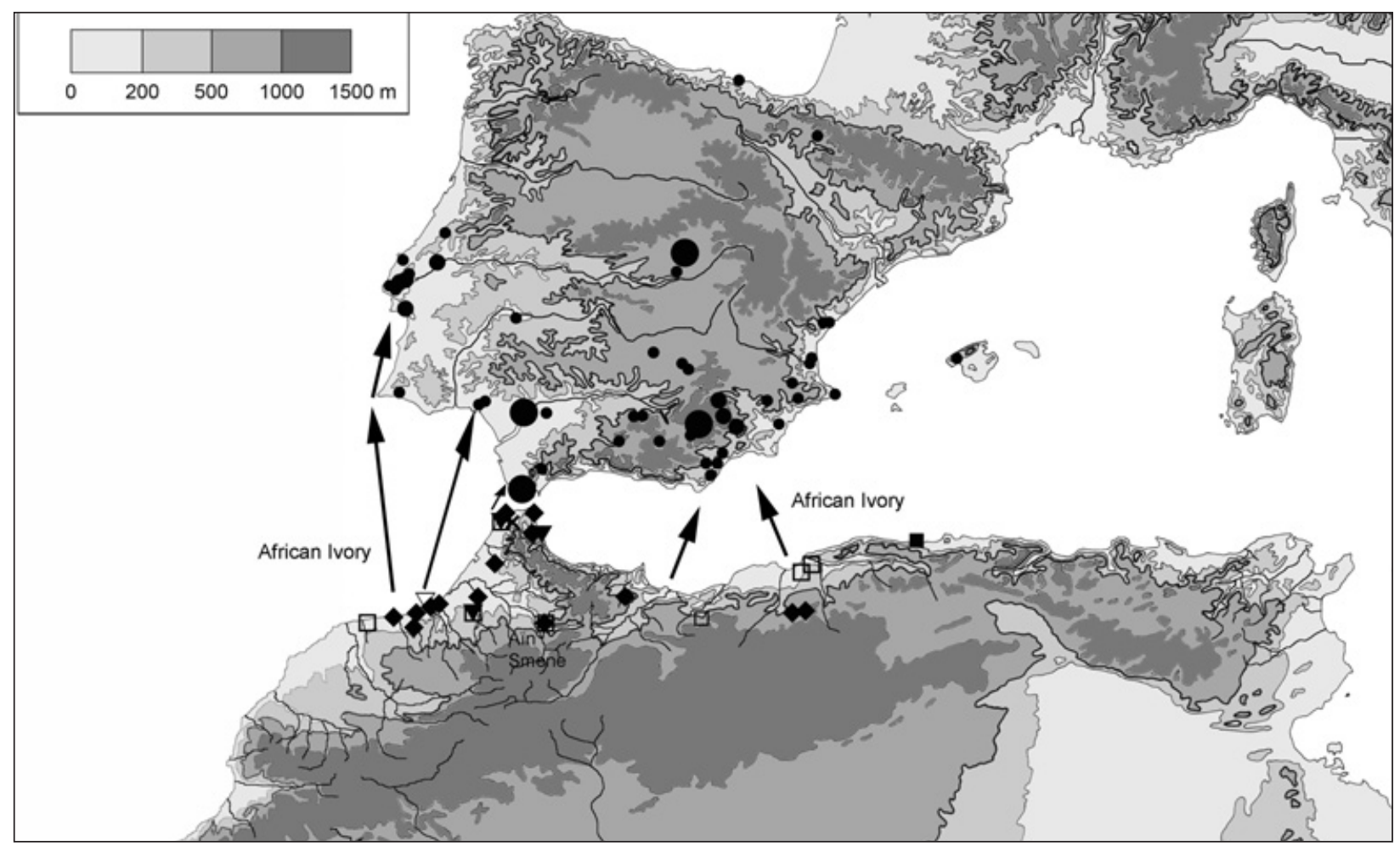

Figure 5. Exchange of ivory and Bell Beaker items between the Maghreb and the Iberian Peninsula. Distribution of ivory objects on the Iberian Peninsula by their number (puntos) in contrast to Bell Beaker objects in the Maghreb: Bell Beakers (rombos), Palmela points (cuadrados vacíos), Copper awls (triángulos negros),

Halberds (X), Tanged daggers (cuadrados negros) and Wrist-guards (triángulos vacíos). 
of African and Asian ivory in the southwestern Iberian Peninsula this region seems to be the most plausible partner for such an exchange. On the contrary, in the Tagus estuary Asian ivory is still missing. On the other hand the similarity between the Bell Beaker complex of the Iberian Southeast and the Maghreb seems to be very limited.

Another possibility would be the exchange of the knot-headed pin from Central Europe or eastern France, where these pins are present at that time, over the Bell Beaker networks towards the Iberian Peninsula, namely the Guadalquivir estuary, and from there in relationship with the import of African ivory to Morocco. So in fact we can recognize a connection between the Iberian Peninsula and especially southern France, as is shown for example by the distribution of Palmela points, some common traits in Bell Beaker decoration, like the existence of vertical elements in the decorative structure, and Bell Beaker morphology and settlement patterns (Briard - Roussot-Larroque, 2002: fig. 4; Salanova, 2000: 191f; Vander Linden, 2004).

In conclusion, we can affirm that a "Cypriot" knotheaded pin found its way from Central Europe or the Eastern Mediterranean to Morocco at the end of the $3^{\text {rd }}$ millennium BC. Although we do have other arguments, deriving from the exchange of Asian ivory between the Near East and the Southwest of the Iberian Peninsula, which could explain how and why this piece reached the West, we are still somehow "Dancing in the Dark" "Therefore we will have to consider both possibilities named for the origin and exchange of this piece, although we would prefer to think that there are more solid arguments for the Mediterranean connection.

\section{ACKNOWLEDGEMENTS}

I would like to thank Mariano Torres (Universidad Complutense Madrid) for giving me hints to similar toilet articles, as well as Alfredo Mederos (Universidad Autónoma de Madrid) for reading the mansucript and all advice.

\section{BIBLIOGRAPHY}

Almagro-Gorbea, M., ed., (2008): Las necrópolis de Medellín. II. Estudio de los hallazgos. Bibliotheca Archaeologica Hispana 26-2. Madrid.

Apellániz, J. M. (1974): "El grupo de Los Husos durante la prehistoria con cerámica en el País Vasco". Estudios de Arqueología Alavesa 7. Vitoria.

\footnotetext{
4 This refers to a song written and performed by Bruce
} Springsteen (1984)
Banerjee, A.; Dindorf, W.; Mikdad, A.; Reischmann, TH.; Schuhmacher, Th. X. (2011): "Die Elfenbeinfunde aus Kehf-el-Baroud (Ziaïda, Ben Slimane, Marokko) und die Frage des Nordafrikanischen Elefanten”. Madrider Mitteilungen 52, 113-138.

Bertram, J.-K. (2002): "Schleifennadelfunde aus dem Kaukasusgebiet". In: R. Aslan et al., eds., Mauerschau. Festschrift für Manfred Korfmann, 815-830. Remshalden-Grunbach.

Bokbot, Y. (2005): "La civilización del vaso Campaniforme en Marruecos y la cuestión del sustrato Calcolítico precampaniforme". In: M. A. Rojo-Guerra; R. Garrido-Pena; I. GarcíaMartínez de Lagrán, eds., El campaniforme en la Península Ibérica y su contexto europeo, 137173. Valladolid.

Bokbot, Y.; Ben-Nçer, A. (2008): "Découvertes campaniformes récentes dans les plateaux de Zemmour (Maroc)". In: M. Baioni et al., eds., Bell Beaker in everyday life, Proceedings of the $10^{\text {th }}$ Meeting «Archéologie et Gobelets», Florence-SienaVillanuova sul Clisi 2006, Millenni. Studi di archeologia preistorica 6, 327-330. Firenze.

Brandherm, D. (1996): "Eine frühbronzezeitliche Schlitzblattlanzenspitze ägäisch-anatolischen Typs aus Südostspanien?" Archäologisches Korrespondenzblatt 26, 263-267.

Briard, J.; Roussot-Larroque, J. (2002): “Les débuts de la métallurgie dans la France atlantique". In: M. Bartelheim; E. Pernicka; R. Krause, eds., Die Anfänge der Metallurgie in der Alten Welt, Forschungen zur Archäometrie und Altertumswissenschaft Band 1, 135-160. Rahden.

Bronk Ramsey, C. (2009): "Bayesian analysis of radiocarbon dates". Radiocarbon 51,1, 337-360.

Castro Martínez, P. V.; Lull, V.; Micó, R. (1996): Cronología de la Prehistoria Reciente de la Península Ibérica y Baleares (c.2800-900 calANE), BAR Int. Series 652. Oxford.

Delattre, A. L. (1897): La nécropole punique de Douïmès (a Carthage). Fouilles de 1895 et 1896. Paris.

Delibes de Castro, G. (1977): El vaso campaniforme en la Meseta Norte española. Studia Archaeologica 46. Valladolid.

Delibes de Castro, G.; Fernández Manzano, J.; Herrán Martínez, J. I. (1999): "Submeseta Norte”. In: G. Delibes de Castro, I. Montero Ruiz, eds., Las Primeras Etapas Metalúrgicas en la Península Ibérica, II. Estudios Regionales, 63-94. Madrid. 
Delibes, G.; Fernández-Miranda, M. (1981): "La tumba de Celada de Roblecedo (Palencia) y los inicios del Bronce Antiguo en el valle medio y alto del Pisuerga". Trabajos de Prehistoria 38, 153-188.

García Sanjuán, L.; Luciáñez Triviño, M.; Schuhmacher, TH. X.; Wheatley, D.; Banerjee, A. (2013): "Ivory craftsmanship, trade and social significance in the southern Iberian Copper Age: the evidence from the PP4-Montelirio sector of Valencina de la Concepción (Seville, Spain)". European Journal of Archaeology 16,4, 610-635.

Garrido Pena, R. (2000): El campaniforme en La Meseta Central de la Península Ibérica (c. 25002000 AC.), BAR International Series 892. Oxford.

Gerloff, S. (1993): “Zu Fragen mittelmeerländischer Kontakte und absoluter Chronologie der Frühbronzezeit in Mittel- und Westeuropa". Prähistorische Zeitschrift 68-1, 58-102.

Grébénart, D. (1988): Les premiers métallurgistes en Afrique occidentale. Paris.

Gutiérrez Saéz, C. et al. (2010): "Puntas de Palmela: procesos tecnológicos y experimentación". Trabajos de Prehistoria 67,2, 405-418.

Harrison, R. J. (1977): The Bell Beaker Cultures of Spain and Portugal. American School of Prehistoric Research. Bulletin 35. Cambridge.

Harrison, R. J.; Gilman, A. (1977): "Trade in the second and third millennia B.C. between the Maghreb and Iberia". In: V.Markotic, ed., Ancient Europe and the Mediterranean, Studies in honour of Hugh Hencken. 90-104. Warminster.

Harrison, R. J.; Bubner, TH.; Hibbs, V. A. (1976): «The Beaker Pottery from El Acebuchal, Carmona (Prov. Sevilla) ». Madrider Mitteilungen 17, 79141.

Hurtado Pérez, V.; Hunt Ortiz, M. A. (1999): "Extremadura". In: G. Delibes de Castro; I. Montero Ruiz, eds., Las Primeras Etapas Metalúrgicas en la Península Ibérica, II. Estudios Regionales. 241-274. Madrid.

Korfmann, M. (1992): “Troia- Ausgrabungen 1990 und 1991". Studia Troica 2, 1-41.

Kunst, M. (1987): Zambujal. Glockenbecher und kerbblattverzierte Keramik aus den Grabungen 1964 bis 1973. Madrider Beiträge 5,2. Mainz.

Lazarich González, M. (2005): “El Campaniforme en Andalucía”. In: M. A. Rojo-Guerra; R. GarridoPena; I. García-Martínez de Lagrán, eds., El Campaniforme en la Península Ibérica y su contexto europeo. 351-387. Valladolid.

Lorrio, A. J. (2008): Qurénima. El Bronce Final del Sureste de la Península Ibérica. Bibliotheca Archaeologica Hispana 27. Real Academia de la Historia. Madrid.
Maran, J. (1998): Kulturwandel auf dem griechischen Festland und den Kykladen im späten 3. Jahrtausend v.Chr.. Studien zu den kuturellen Verhältnissen in Südosteuropa und dem zentralen sowie östlichen Mittelmeerraum in der späten Kupfer- und frühen Bronzezeit. Universitätsforschungen zur prähistorischen Archäologie 53. Bonn.

Mederos Martín, A. (2000): "Puntas de jabalina de Valencina de la Concepción (Sevilla) y del área palestino-israelita". Madrider Mitteilungen 41, 83-111.

Miketta, F. (2011): "Der Hortfund von Kyhna und frühbronzezeitliche Kulturkontakte". Berichte zur Archäologie in Rheinhessen und Umgebung 4, 85-95.

Montero Ruíz, I.; Bokbot, Y.; Murillo-Barroso, M.; Gener Moret, M. (2012): "Metalurgia pre-islámica en Marruecos: Nuevos análisis y valoración comparativa con la metalurgia de la Península Ibérica". Estudos Arqueológicos de Oeiras 19, 113-118.

Nocete, F.; Vargas, J. M.; Schuhmacher, TH. X.; Banerjee, A.; Dindorf, W. (2013): "The ivory workshop of Valencia de la Concepción (Seville, Spain) and the identification of ivory from Asian elephant on the Iberian Peninsula in the first half of the $3^{\text {rd }}$ millennium B.C". Journal of Archaeological Science 40,1579-1592.

Osuna Ruiz, M.; Remesal Rodríguez, J. (1981): “La necrópolis de Boliche (Villaricos-Almería)". Archivo de Prehistoria Levantina 16, 373-416.

Ponsich, M. (1970): Recherches archéologiques à Tanger et dans sa région. Paris.

Poyato Holgado, C.; Hernando Grande, A. (1988): "Relaciones entre la Península Ibérica y el Norte de Africa: „Marfil y campaniforme“. In: Actas del Congreso Internacional „El Estrecho de Gibraltar", Ceuta 1987, Bd. I, 317-329. Madrid.

Rovira, S.; Montero, I.; Consuegra, S. (1992): "Archaeometallurgical study of Palmela arrow heads and other related types". In: E. Antonacci, ed., Archeometallurgia richerche e perspettive. Atti del Colloquio Internazionale di BolognaDozza Imoleste 1988, 269-298. Bolonia.

Rovira, S.; Montero, I.; Ortega; J.; Jiménez Ávila, J. (2005): "Bronce y trabajo del bronce en el poblado orientalizante de "El Palomar" (Oliva de Mérida, Badajoz)". In: S. Celestino Pérez; J. Jiménez Ávila, eds.; El Periodo Orientalizante, vol. II. Actas del III Simposio Internacional de Arqueología de Mérida: Protohistoria del Mediterráneo Occidental. Anejos de Archivo Español de Arqueología XXXV, 1231-1240. Mérida. 
Salanova, L. (2000): La question du Campaniforme en France et dans les îles anglo-normandes. Paris.

Santos; F. J. C.; Tamissa Antunes, A. S.; Grillo, C.; De Deus, M. (2010): “A necrópole da I Edade da Ferro de Palhais (Beringel, Beja): resultados preliminares de uma intervenção de emergência no BaixoAlentejo". In: J. A. Pérez Macías; E. Romero Bomba, eds., IV Encuentro de Arqueologia del Suroeste Peninsular. Digital Edition, 32.

Schuhmacher, Th. X. (2004): "Frühbronzezeitliche Kontakte im westlichen und zentralen Mittelmeerraum und die Rolle der Iberischen Halbinsel". Madrider Mitteilungen 45, 147-180.

Schuhmacher, Th. X. (2012): Die Elfenbeinobjekte des Chalkolithikums und der Frühen Bronzezeit auf der Iberischen Halbinsel. Interdisziplinäre Studien zu Herkunft, Austausch, Verarbeitung und sozialer Bedeutung von Elfenbein, Iberia Archaeologica 16,2. Darmstadt/Mainz.

Schuhmacher, Th. X. (unpublished): Kontakte, Handel und Schiffahrt im westlichen und zentralen Mittelmeer. Die Rolle der Iberischen Halbinsel am Beginn der Bronzezeit, Habilitationsschrift Universität Bamberg.

Schuhmacher, Th. X. (in press): Elefanten und Elfenbein auf der Iberischen Halbinsel und in Nordwest-Afrika. Interdisziplinäre Studien zu Austauschsystemen im 3. und der ersten Hälfte des 2. Jts. v. Chr., Iberia Archaeologica 16,3. Darmstadt/Mainz.
Siret, L. (1906): Villaricos y Herrerías. Antiguedades púnicas, romanas, visigóticas y árabes. Reprint 1985. Madrid.

Siret, L. (1913): Questions de chronologie et d'éthnographie iberiques. Paris.

Soares, J.; Tavares da Silva, C. (1984): "Le groupe de Palmela dans le cadre de la céramique campaniforme au Portugal". In: J. Guilaine, ed., L'âge $d u$ cuivre européen. Civilisations à vases campaniformes. 209-220. Paris.

Souville, G. (1965): "Influences de la Péninsule Ibérique sur les civilisations postnéolithiques du Maroc". In: E. Ripoll Perelló, ed., Miscelánea en homenaje al Abate Henri Breuil (1877-1961), tomo II. 409-422. Barcelona.

Souville, G. (1989): "Présence du chalcolithique au Maroc Central”. Bulletin archéologique du Comité des Travaux historiques et scientifiques 20-21, 1984-1985, 7-15.

Vander Linden, M. (2004): "Polythetic networks, coherent people: a new historical hypothesis for the Bell Beaker phenomenon”. In: J. Czebreszuk, ed., Similar But Different. Bell Beakers in Europe. Poznań.

Wengler, L. (1983/84): “La grotte d’El Hériga (Maroc Oriental). Note préliminaire". Bulletin d'Archéologie Marocaine 15, 81-90. 